\title{
Rubella Virus-associated Anterior Uveitis in a Vaccinated Patient: A Case Report
}

\author{
Josianne C. E. M. ten Berge, Paul L. A. van Daele \& Aniki Rothova
}

To cite this article: Josianne C. E. M. ten Berge, Paul L. A. van Daele \& Aniki Rothova (2016) Rubella Virus-associated Anterior Uveitis in a Vaccinated Patient: A Case Report, Ocular Immunology and Inflammation, 24:1, 113-114, DOI: 10.3109/09273948.2014.925126

To link to this article: http://dx.doi.org/10.3109/09273948.2014.925126

\section{册 Published online: 19 Jun 2014.}

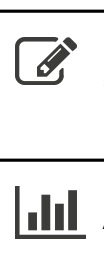

Submit your article to this journal ¿

川 Article views: 235

Q View related articles $₫$

View Crossmark data $\asymp$

4 Citing articles: 1 View citing articles 


\title{
Rubella Virus-associated Anterior Uveitis in a Vaccinated Patient: A Case Report
}

\author{
Josianne C. E. M. ten Berge, $\mathrm{MD}, \mathrm{MSc}^{1}$, Paul L. A. van Daele, $\mathrm{MD}, \mathrm{PhD}^{2}$, and \\ Aniki Rothova, $\mathrm{MD}, \mathrm{PhD}^{1}$ \\ ${ }^{1}$ Department of Ophthalmology, Erasmus MC, University Medical Center Rotterdam, \\ Rotterdam, The Netherlands, and ${ }^{2}$ Department of Immunology, Erasmus MC, University Medical Center \\ Rotterdam, Rotterdam, The Netherlands
}

\begin{abstract}
Rubella virus is involved in the pathogenesis of Fuchs heterochromic uveitis and almost all cases in Europe show an active antibody production in the aqueous humor against rubella virus. Herein we report a case of a fully vaccinated patient with common variable immunodeficiency who developed unilateral Fuchs heterochromic uveitis secondary to rubella virus which was proven by intraocular fluid examination. Awareness of rubella associated anterior uveitis should remain also in vaccinated patients, especially those without a fully competent immune system.
\end{abstract}

Keywords: Fuchs heterochromic uveitis, immunocompromised, rubella virus, uveitis anterior, vaccination

Rubella virus (RV) is involved in the pathogenesis of Fuchs heterochromic uveitis (FHU) and almost all cases of FHU in Europe show an active antibody production in the aqueous humor against RV. ${ }^{1}$ Positive polymerase chain reaction (PCR) for RV is, however, scarcely detected, probably due to chronic stage of the infection at the time of intraocular sample collection. The incidence rate of FHU cases has significantly decreased since the introduction of the rubella vaccination schedule. ${ }^{2}$ Herein we report a case of a fully vaccinated patient who developed unilateral FHU secondary to RV.

A 28-year-old man was referred with unilateral uveitis, not responding to anti-inflammatory treatment. His complaints included gradual vision loss in primarily the right eye since 1 year. Medical history of the patient includes a parotic extranodular marginal zone non-Hodgkin B-cell lymphoma at the age of 21, for which he was treated with local radiotherapy. Additionally, he was diagnosed with a common variable immune deficiency (CVID). CVID is a form of immune deficiency that is characterized by a decreased but not absent antibody production. Since childhood he has suffered from recurrent upper respiratory tract infections. Currently he receives regular immunoglobulin supplementation. Ophthalmic examination revealed a corrected visual acuity of $0.8++$ of the right eye and 1.5- of the left eye. Intraocular pressure was $9 \mathrm{mmHg}$. There was no conjunctival injection and slit-lamp examination of the right eye disclosed fine keratic precipitates diffusely scattered across the corneal endothelium, anterior chamber cells and a slight opalescence, diffuse iris atrophy with transillumination, and fine nodules at the pupillary border. No synechiae were found. Fundus investigation and the optic disc showed no abnormalities. The left eye exhibited no anomalous findings. Aqueous examination showed anti-rubella IgG in a titer of $2560 \mathrm{UI} / \mathrm{mL}$ (which was higher than his serum titer of $1280 \mathrm{UI} / \mathrm{mL}$ ), and resulted in a Goldmann-Witmer coefficient (GWC) of 182. The PCR and GWC for herpes simplex virus 1 and 2, cytomegalovirus, varicella zoster virus, and Epstein Barr virus were negative as well as the PCR 
for RV. All additional screening results for uveitis (including a chest $\mathrm{x}$-ray, a Mantoux test, serum angiotensine-converting-enzyme levels, and serology for Borrelia burgdorferi, Toxoplasma gondii, and Treponema pallidum) remained within the normal limits. The diagnosis of RV-associated uveitis was made and it became apparent that his uveitis has no relation to previous lymphoma, but that regular ocular controls were required. Minimal use of topical corticosteroid medication was prescribed since it is known that corticosteroids have less beneficial effects in RV-associated uveitis and might contribute to cataract and glaucoma development.

Systemic RV infections occurring in fully RV-vaccinated patients have already been reported. ${ }^{3}$ The duration of rubella immunity induced by 2-dose RV vaccination has resulted in a low level of antibodies against RV 15 years after vaccination in up to $31 \%$. The patient received rubella vaccination at the ages of 4 and 9. The vaccination status was confirmed by the National Institute for Public Health and the Environment.

The titers of antibodies against rubella determined at the age of 24 and 28 were high and protective in contrast to his marginal titer of antibodies against mumps and measles, which suggests a real previous infection with rubella virus. So far, the efficacy data of $R V$ vaccination in immunocompromised patients are lacking. We hypothesize that the RV-associated uveitis in this fully vaccinated but immunocompromised patient might have developed due to an insufficient reaction to vaccine or to a premature loss of immunity against RV despite the vaccination, probably also caused by the immunodeficiency. Influence of the treatment of the non-Hodgkin B-cell lymphoma on the development of rubella-associated uveitis is not likely, since he was treated with local radiotherapy.

To our knowledge this is the first report showing RV-associated FHU in a fully vaccinated patient. Rubella vaccination does not provide protection for everyone and reinfections with RV are possible. Our case indicates that awareness of rubella-associated anterior uveitis should also remain in vaccinated patients, especially those without a fully competent immune system.

\section{DECLARATION OF INTEREST}

The authors report no conflicts of interest. The authors alone are responsible for the content and writing of the paper.

\section{REFERENCES}

1. Quentin CD, Reiber H. Fuchs heterochromic cyclitis: rubella virus antibodies and genome in aqueous humor. Am J Ophthalmol. 2004;138:46-54.

2. Birnbaum AD, Tessler $\mathrm{HH}$, Schultz $\mathrm{KL}$, et al. Epidemiologic relationship between Fuchs heterochromic iridocyclitis and the United States Rubella Vaccination Program. Am J Ophthalmol. 2007;144:424-428.

3. Aboudy Y, Barnea B, Yosef L, et al. Clinical rubella re-infection during pregnancy in a previously vaccinated woman. J Infect. 2000;41:187-189.

4. Davidkin I, Peltola H, Leinikki P, Valle M. Duration of rubella immunity induced by two-dose measles, mumps and rubella (MMR) vaccination: a 15-year follow-up in Finland. Vaccine. 2000;18:3106-3112. 